\title{
Communication Patterns in Online University Lectures: Cross-Cultural Comparison between Czechia \& Indonesia
}

\author{
Natan Ledvoň ${ }^{1}$, Nurhayati ${ }^{2}$ \\ ${ }^{1}$ Student, Department of Linguistics, Faculty of Humanities, Diponegoro University, Indonesia \\ ${ }^{2}$ Lecturer, Department of Linguistics, Faculty of Humanities, Diponegoro University, Indonesia
}

\begin{abstract}
The goal of the paper is to observe and compare the communication patterns in online university lectures occurring in the Czech and Indonesian (more specifically Javanese) environment through the lens of the ethnography of communication, based on the theory of speech acts. It aims to offer an insight in form of a case study and complement the knowledge in this field, especially considering the rapid expansion of the discourse due to the world pandemic in which information systems play a crucial role. The practical part uses direct observation of a set of classes to reveal how the same studied communicative events are practised differently. One of the key findings is the confirmation of my hypothesis that the speech events in the studied case show cultural differences and it is beneficial to study them through the lens of ethnography of communication. The focus on speech acts proved to be a crucial tool in my analysis.
\end{abstract}

\section{Introduction}

Communication lies at the very core of language study. Should we choose the synchronic or diachronic perspective, different schools of thought, or even see the language through the lens of semiotics, communication remains by far the primary function of human language. Language was, is and remains the primary tool of communication between people.

Being part of what de Saussure would call "parole" [1], communication is essential in the practical everyday use of language and carries a central role in sharing (from Latin "communicate" [2]). Transmission is highly variable depending on several internal and external linguistic and extra-linguistic factors, such as "ethnicity (or cultural background). Despite the complex issue surrounding the definition of ethnic groups in recent years, there is no doubt that one's cultural background is highly influential in language use. It is not the aim of this article to examine all the background, but the crucial concepts will be explained in the theoretical part of the paper.

It has been a linguistic trend to study online communication for its exceptional growth in frequency as it has become an essential part of many of today's societies and cultures during the last 20 years. One of the endless forms of communication is between students and teachers in classroom settings.

Online lectures are where "online communication" and "classroom communication" meet. It is also where "ethnicity" can be found at work. In what follows, I will describe the

*Correspondence author: natanledvon@students.undip.ac.id 
communication patterns taking place in online lectures and compare the differences between these in Czech and Indonesian university settings. I am not going to be exhaustive, but I will point out several findings based on the unique opportunity I was given during the pandemic of the so-called covid19. As a university student taking lectures both in Czechia and Indonesia, I decided to do this case study of two seemingly similar yet quite distinct examples of the same communicative situation (online class) that vary in their communicative events, especially their particular speech acts..

\section{Theory and Methodology}

My study is based on the perspective of the ethnology of communication that Hymes introduced. Communication here is seen as the spoken form of what de Saussure would call "parole" (i.e. the practical use of language). The approach understands it as determined by several factors related to the society or culture the speaker belongs to. Therefore, we can see the ethnography of communication research as a specific type of linguistic discourse analysis [3].

One of the key terms in the ethnography of communication is speech communities. According to Yule, these are defined as "groups of people who share a set of linguistic norms and expectations regarding the use of language" [4]. Labov further extended the idea claiming that "The speech community is not defined by any marked agreement in the use of language elements, so much as by participation in a set of shared norms: these norms may be observed in overt types of evaluative behaviour, and by the uniformity of abstract patterns of variation which are invariant in respect to particular levels of usage." [5]. His definition of speech community has been the starting point for building the methodology and practical part of my research.

Due to its comparing nature, there are two speech communities examined in this study. The first one is made of the (relatively larger) Indonesian academic environment, while the second one is the Czech academia. In the case of the first group, which is very extensive and significantly more diverse, I will focus on Javanese public universities, while in the case of much more homogenous case of the Czech Republic, I am not going to define the group geographically in more detail. However, the focus is kept on local public higher education institutions as well.

According to Austin, speech acts are "something expressed by an individual that not only presents information but performs an action as well" [6]. In other words, what say often has hidden contextual meanings, which can depend on cultural background. The speech acts from communicative events depending on the purpose of the interaction.

Regarding previous studies on the topic, to my knowledge, there has been no published attempt to study online university lectures through the lens of ethnography of communication. However, studies applying the theory focus on the classroom environment, such as An Ethnography of Communication in Immersion Classrooms in Hungary [7]. Radfords, Connaway and DeAngelis belong to those who combined the approach with the online environment in their contribution, On Virtual Face-Work: An Ethnography of Communication Approach to a Live Chat Reference Interaction [8].

I base my methodology primarily on direct observation of chosen classes (including their recordings) and secondarily on data obtained by direct interviewing combined with online questionnaires presented to a set of students from the studied speech communities. The data collection was focused on the speech acts performed by teachers (not students), and the semistructured interviewing focused on the following areas:

- Student identification (university affiliation, nationality and level of study)

- Structure of their typical online lectures

- Examples of speech acts performed by the teachers 


\section{Units of Analysis \& Discussion}

\subsection{Communicative situation}

The studies situation is situated in the online environment of university lectures. The collected data comes from various classes (graduate and undergraduate level from several universities and faculties). They are mainly of the same length (i.e. around 90 minutes in total) and most commonly using online teaching/learning software such as Microsoft Teams or Zoom. The communicative situation is the exact core nature, anchored in university settings' knowledge and teaching context. However, the studied material is specific for happening in the online space instead of face to face.

\subsection{Communicative events}

This this is where I observed significant differences. In the Czech academic environment, there are traditionally two types of lectures: přednáška (lesson) and seminár (seminar). Although there still tends to be a clear distinction between the two in face-to-face lectures, these differences seem less significant in the online environment. On the other hand, in Indonesia, to my knowledge, such a distinction does not exist.

Indonesian online lectures appear to be more complex in the number of communicative events due to what I prefer to call cultural and environmental distractions. These influences lead to different communicative events that are not directly related to the teaching/learning process. I argue they are either effect of cultural patterns that come from within (a deeper level of cultural patterns of the Indonesian speech community) or results of other external factors.

From my observation, these are the communicative events typical for the Czech online university classes:

- Introduction (usually present)

- Teaching (usually present)

- Discussion (sometimes present)

- Conclusion (usually present)

In the Indonesian online university lectures settings additional communicative events often appear:

- Introduction (usually present)

- Absence (usually present)

- Teaching (usually present)

- Discussion (usually present)

- Prayer break (rarely present)

- Blackout break (occasionally present)

- Conclusion (usually present)

The order of the communicative events mentioned can vary. In the brackets, I state the approximate frequency of occurrence in the lectures I studies.

\subsection{Communicative actions}

These are the lists of some of the most commonly used speech samples in the studied data according to their respective communication event:

Table 1. Introductory greetings in Czech.

\begin{tabular}{|l|l|}
\hline Czech speech sample & English translation \\
\hline
\end{tabular}




\begin{tabular}{|l|l|}
\hline Dobrý den & Good day \\
\hline Tak vás zdravím & So I greet you \\
\hline Dobré odpoledne & Good afternoon \\
\hline Jak se vám daří? & How are you? \\
\hline Slyšíme se? & Can we hear each other? \\
\hline Tak dobré ráno & Well, good morning \\
\hline
\end{tabular}

We can see the introductory greetings in Czech tend to be simple, which can be a result of the general tendency in what some would call "western culture" to reduce and simplify formalities.

Table 2. Discussion in Czech.

\begin{tabular}{|l|l|}
\hline Czech speech sample & English translation \\
\hline Chcete se na něco zeptat? & Da you want to ask something? \\
\hline Jaký je váš názor? & What is your opinion? \\
\hline Co si o tom myslíte? & What do you think about it? \\
\hline To je z me strany vše & This is all from my side. \\
\hline Proč si to myslíte? & Why do you believe so? \\
\hline Máte nějaké otázky? & Have you got any questions? \\
\hline
\end{tabular}

Czech teachers show a greater tendency to encourage students to build their views. While their Indonesian counterparts sometimes seem to focus on making sure students understand what had been thought, Czech lecturers emphasise creating an environment where different opinions are raised and are treated equally by presenting arguments from each side. This can be since "western thinking" is traditionally [9] more individualistic, which is generally true even for the Czech academia. 
Table 3. Concluding greetings in Czech.

\begin{tabular}{|l|l|}
\hline Czech speech sample & English translation \\
\hline Na shledanou & Goodbye \\
\hline Tak zase př́ští týden & So next week again \\
\hline Uvidíme se př́ští týden & See you next week \\
\hline Mějte se dobře/krásně/hezky & Have a goodgreat/nice time \\
\hline To je pro dnešek vše & This is all for today \\
\hline Děkuji za pozornost & Thank you for your attention \\
\hline Děkuji za účast & Thank you for being here \\
\hline Budu se na vás těšit & $\begin{array}{l}\text { I will be looking forward to seeing } \\
\text { you }\end{array}$ \\
\hline
\end{tabular}

Teachers like to make a connection with the following lecture and sometimes comment more about this connection. It seems that saying goodbye can be relatively prolonged from the teacher's side while the student does not necessarily respond (each of them) to the goodbye.

Table 4. Introductory greetings in Indonesian.

\begin{tabular}{|l|l|}
\hline Indonesian speech sample & English translation \\
\hline Assalamu aleykum wrwb & Peace be upon you \\
\hline Selamat sore semua & Good afternoon everyone \\
\hline
\end{tabular}

Some of the Indonesian greetings include religious phrases. In the case of Java, where most university lecturers are Muslims, this is clear in using Arabic greeting used and one of the official greetings in Indonesian (although not the only ones). This might be related to the perceived identity of the teachers rather than the students.

Table 5. Attendance in Indonesian.

\begin{tabular}{|l|l|}
\hline Indonesian speech sample & English translation \\
\hline Silahkan presensi dulu & Please do your attendance \\
\hline Absenkan dulu & Do your attendance \\
\hline Siapa yang belum absen? & Who has not done the attendance yet? \\
\hline Ada yang belum absen? & $\begin{array}{l}\text { Is there anyone who has not done the } \\
\text { attendance yet? }\end{array}$ \\
\hline
\end{tabular}


Indonesian online lectures usually include a phase of noting students' attendance. Although there is no regulation for this in Indonesia, there seems to be more emphasis on this issue. This is less common in the Czech context because most lectures (especially the Přednáška/Lesson are optional (it is up to the students whether they attend or not, the key is to pass the exam later). The attendance in Indonesian classes is done either using external software or by calling out students' names.

Table 6. Discussion in Indonesian.

\begin{tabular}{|l|l|}
\hline Indonesian speech sample & English translation \\
\hline Ada pertanyaan? & Any questions? \\
\hline Ada yang mau tanya? & Is there anyone who wants to ask? \\
\hline Kita diskusi dulu & Let us discuss \\
\hline Monggo mempertanyakan & Ask me \\
\hline $\begin{array}{l}\text { Mungkin ada yang mau ditanyakan di } \\
\text { audience ini? }\end{array}$ & $\begin{array}{l}\text { Maybe there is a question from the } \\
\text { audience? }\end{array}$ \\
\hline Sampai sekarang ada pertanyaan? & Is there a question till now? \\
\hline Sejauh ini ada pertanyaan? & Is there a question until now? \\
\hline (Nama), silahkan bertanya & (Name), you can ask a question \\
\hline
\end{tabular}

It seems to be slightly more typical to combine teaching and discussion into lectures that look more like an interview or group discussion as questions and answers are given during the teaching/learning phase. This happens in the Czech context but appears to be mostly separated into the teaching/learning and discussion phase. Indonesian teachers sometimes ask students individually if they have a question or even directly ask one, which is relatively unknown to the Czech context.

Table 7. Prayer break in Indonesian.

\begin{tabular}{|l|l|}
\hline Indonesian speech sample & English translation \\
\hline $\begin{array}{l}\text { Saya ingin sholat dulu iya, kita lanjut } \\
\text { dalam .... menit }\end{array}$ & $\begin{array}{l}\text { I would like to pray now, we are } \\
\text { going to continue in ... minutes }\end{array}$ \\
\hline
\end{tabular}

Although more common on the student side, it is interesting that Muslim lecturers occasionally pause the lesson for the obligatory prayers. This tends to be silently accepted but might be considered inappropriate in the Czech context, one of the most atheistic in the world [10] and where faith is regarded as a personal matter. This appears to be unique to the online environment, supposedly thanks to the ease of such a break compared to lectures in the classroom (timed differently). 
Table 8. Blackout break in Indonesian.

\begin{tabular}{|l|l|}
\hline Indonesian speech sample & English translation \\
\hline Saya minta maaf & I apologize \\
\hline Tadi listrik di tempat saya mati & $\begin{array}{l}\text { The electricity in my place has gone } \\
\text { out }\end{array}$ \\
\hline
\end{tabular}

Due to the environmental conditions at my research, I have occasionally encountered breaks in the lectures cause by electricity blackouts. The teachers usually apologized, and the situation was not handled with surprise. The above is an example only, as similar situation raised for instance in slower internet connection due to heavy raining. This is mostly absent in the Czech settings, where technical breaks seem to occur more as a result of issues with hardware and software on the teacher (or student) side.

Table 9. Concluding greetings in Indonesian.

\begin{tabular}{|l|l|}
\hline Indonesian speech sample & English translation \\
\hline $\begin{array}{l}\text { Sampai kita ketemu minggu depan } \\
\text { lagi }\end{array}$ & Let us meet next week again \\
\hline $\begin{array}{l}\text { Jaga kesehatan dan protokol } \\
\text { kesehatan }\end{array}$ & $\begin{array}{l}\text { Stay healthy and keep the health } \\
\text { protocol }\end{array}$ \\
\hline Cepat mandi & Wash on time \\
\hline Assalamu aleykum & Peace be upon you \\
\hline Terima kasih atas bersamaan kita & Thank you for being together \\
\hline Sudah, kita lanjutkan minggu depan & Done, we can continue next week \\
\hline Mohon maaf saya iya & Please forgive me, okay? \\
\hline
\end{tabular}

Saying goodbye is faster in the Indonesian context compared to the Czech settings. Although Indonesian teachers may prolong the ending phase, it is more typical for the Czech side. This is true even for the studied online communicative situation. Indonesian greetings tend to be more personal and sometimes include religious phrases as well as introductory greetings (for example, apologizing for possible mistakes).

\section{Conclusion}

The study has provided a linguistic insight into the two worlds of Czech and Indonesian online classes' environments. As assumed, notable differences were observed in the process of analyzing the studied cases. The same communicative situation in two different cultural contexts was compared in a case study by analyzing speech samples from collected data in the Czech and Indonesian environments.

On the descriptive level, a higher level of complexity in communication was identified on the side of Indonesian lectures, which is clear from the considerably more elevated amount of observed communicative events. The subsequent comparison revealed the most significant 
difference in communication (from the linguistic point of view) to be the standard inclusion of religious speech in Indonesia instead of its complete exclusion in Czechia. Religious speech segments form essential elements, especially in (both introductory and concluding) greetings used in the Javanese academic settings. Lastly, online lectures proved to have their specifics on the explanatory level, which can be identified from the obtained data. There are specific challenges and unique speech acts observed in the online learning/teaching environment. For instance, Indonesian online classes more typically involve both cultural (relatively longer religious greetings) and environmental (technical issues) "distractions". Although these might be perceived as redundant by the Czech counterpart, they seem to contribute even more to the already encouraging personal connection between teachers and students. I argue that these are rather barrier breakers than disturbances.

It ought to be mentioned that my research has certain limitations, especially considering my narrow focus on chosen cases. Moreover, other extralinguistic factors might contribute to the final forms of observed communication, including particular speech acts. Software choice and its functions or use of video conferencing within the class can serve as examples of such influences. Therefore, further research considering these are recommended.

\section{References}

1. F. de Saussure, Course in general linguistics (1916)

2. J. D. Peters, Communication: History of the Idea. The International Encyclopedia of Communication (2008)

3. D. Hymes, The Ethnography of Speaking (1962)

4. G. Yule, The Study of Language (2006)

5. W. Labov, Sociolinguistic Patterns (1972)

6. J. Langshaw, Austin, How to do Things with Words (1962)

7. P. A. Duff, An Ethnography of Communication in Immersion Classrooms in Hungary, TESOL Quarterly 29/3, 505-537 (1995)

8. M. L. Radford et al. On Virtual Face-Work: An Ethnography of Communication Approach to a Live Chat Reference Interaction, The Library Quarterly: Information, Community, Policy, 81/4, 431-453 (2011)

9. S. Mencher, Individualism in Modern Western Culture, The Southwestern Social Science Quarterly, 28/3, 257-63 (1947)

10. T. V. Smith, Beliefs about God across Time and Countries (2012) 